\title{
25 Research Square \\ GC-MS analysis of bioactive compounds in ethanolic leaf extract of Hellenia speciosa (J.Koenig) S.R.Dutta
}

Ramya Raveendran ( $\sim$ ramya.r@jbascollege.edu.in ) Justice Basheer Ahmed Sayeed College for Women https://orcid.org/0000-0002-6035-958X

\section{Research Article}

Keywords: Phytochemicals, Bioactive compounds, GC-MS analysis, Pharmacological, Costaceae

Posted Date: July 28th, 2021

DOI: https://doi.org/10.21203/rs.3.rs-743090/v1

License: (c) (1) This work is licensed under a Creative Commons Attribution 4.0 International License.

Read Full License 


\section{Abstract}

Hellenia speciosa (J.Koenig) S.R.Dutta, is a plant species belonging to the family Costaceae. It is widely distributed in China, India, Malaysia, Indonesia, tropical and subtropical Asia. In Ayurveda, the rhizome of the plant has been extensively used to treat fever, rash, asthma, bronchitis and, intestinal worms. The objective of the present study was to investigate the phytochemical constituents of the leaf of Hellenia speciosa using Gas Chromatography and Mass Spectroscopy analysis (GC-MS). The GC-MS analysis revealed the presence of 17 phytochemical components in the ethanolic leaf extract of Hellenia speciosa. The prevailing bioactive compounds present in Hellenia speciosa were Thymol (RT-10.019;3.59\%), Caryophyllene (RT-11.854:0.62\%), Caryophyllene oxide (RT-13.919;1.34\%), Artumerone (RT-14.795;1.35\%), Hexadecanoic acid methyl ester (RT-17.536; 2.77\%), 9,12-Octadecanoic acid methyl ester (RT19.163;1.35\%), Squalene (RT- 24.980;1.19\%), Piperine (RT-25.745;3.11\%), Beta Tocopherol (RT26.681;2.88\%) Vitamin E (RT- 27.290;2.64\%), Progesterone (RT-29.608;3.18\%), Caparratriene (RT$29.861 ; 9.72 \%$ ), and Testosterone (RT-30.73;5.81\%). The compounds were identified by comparing their retention time and peak area with that of the literature and by interpretation of mass spectra. The results and findings of the present study suggest that the plant can be used as a valuable source in the field of herbal drug discovery. The presence of bioactive compounds justifies the use of plant leaves for treating various diseases with fewer side effects and recommended the plant of pharmaceutical importance. However, further studies are needed to undertake its bioactivity and toxicity profile.

\section{Introduction}

Medicinal plants are the traditional source of chemical compounds in the field of biotechnology for the discovery of herbal medicine. Most of the pharmaceutical industries depend on these plants for the secondary metabolites for the development of health care products. The secondary metabolites are the phytochemical constituents present in the crude extracts of the plants [1]. In India, there is an increasing demand for natural products from plant sources due to their medicinal properties and safety issues. According to World Health Organization, about $80 \%$ of the population follow plant-based traditional medicines for primary healthcare [2]. Traditional systems of medicines are prepared from a single plant species or combinations of several plants species. The bioactive component of the plant may be derived from any parts of the plant like leaves, roots, bark, flowers, fruits, and seeds [3]. Plant-based medicines that are derived from crude leaf extracts contain different phytochemicals. These phytochemicals are the bioactive principles having a unique and complex structure to treat various ailments. Screening of plants by chromatographic methods provides information on its pharmacological activities which help to select the plant of medicinal property [4]. Gas chromatography-mass spectrometry (GC-MS) is the accurate technique employed for the detection of functional groups and identification of various bioactive therapeutic compounds that are present in medicinal plants [5], [6]. Hence in the present study, the GCMS technique was adopted for the detection and identification of phytochemical compounds present in the medicinal plant, Hellenia speciosa belonging to the Costaceae family. 
Hellenia speciosa is one such plant with medicinal importance. It is a perennial herb mainly cultivated in the rainy season and grows well in clayey loam soil [7]. It can be propagated by different methods such as stem cutting, division of clumps, or rhizome [8]. The plant has many medicinal uses, juice of rhizome is applied to the head for cooling and relief from headache, bruised leaves are applied in fever, a decoction of the stem is used in fever and dysentery. The leaf infusion or decoction from leaves, young stems are used against diarrhoea, cough, cuts, wounds, scabies, the antidote for snakebite, jaundice, arthritis [9], burning sensation, constipation, leprosy, skin diseases, asthma, bronchitis, inflammations, anaemia, intestinal worm infection [10]. The leaves and rhizomes of Hellenia speciosa have been reported to possess steroid - diosgenin, which is anti-diabetic in nature. The Leaves also possess hypoglycaemic properties and insulin potentiating action in addition to decreasing blood glucose [11]. In Indian traditional medicine, Hellenia speciosa rhizome was found to possess anthelmintic, antiinflammatory, antidiabetic, hepatoprotective, antihyperlipidemic, antispasmodic, and antimicrobial activities [12],[13]. In this paper, the GC-MS analysis of leaf extract has been studied as part of the exploration for bioactive compounds.

\section{Materials And Methods}

\section{Collection of Plant Material}

Hellenia speciosa was collected from Thrissur district of Kerala, taxonomically identified and confirmed by the botanist Dr. S. Ravikumar, PG and Research Department of Plant Biology and Biotechnology, Presidency College, Chennai. [Voucher specimen no. PCMRDRM2017001] (Fig. 1, Fig. 2). The leaves were washed with water, shade dried at room temperature, and powdered in an electric blender as shown in Fig. 3. The powdered leaves were stored in an opaque container at room temperature for further analysis.

\section{Preparation of Plant Extract}

Preparation of plant extracts was done according to the combination of the methods described by Pizzale and Lu and Foo [14],[15]. About $1 \mathrm{~g}$ of fleshy dried powder of Hellenia speciosa plant materials was extracted with $20 \mathrm{~mL}$ ethanol for 1 min using an Ultra Truax mixer (13,000 rpm) and soaked overnight at room temperature. The sample was then filtered through Whatman No. 1 paper in a Buchner funnel. The filtered solution was evaporated under vacuum in a rota-evaporator at $40^{\circ} \mathrm{C}$ to a constant weight and then dissolved in respective solvents. The dissolving rate of the crude extracts was approximately $100 \%$. The solution was stored at $18^{\circ} \mathrm{C}$ until use.

\section{GC-MS Analysis}

Gas chromatography-mass spectrometry (GC-MS) is an analytical method that combines the features of gas-chromatography and mass spectrometry to identify different substances within a test sample [16]. GC-MS analysis was carried out to identify some of the potent volatile and semi-volatile constitutes present in the ethanol extract of Hellenia speciosa. GC-MS analysis was carried out on the GC-MS-5975C Agilent system comprising an autosampler and gas chromatograph interfaced to a mass spectrometer 
employing the following condition. The sample was injected into the injected port of the Gas chromatography (GC) device. The GC instrument vaporizes the sample and then separates and analyses the various components. Each component produces a specific spectral peak that may be recorded on a paper chart electronically. The time elapsed between elution and injection is called the "retention time". Differentiate between some compounds was identified using the Retention time. The peak is measured from the base to the tip of the peak [17].

\section{COLUMN}

Column Elite - 1 fused silica capillary column (30x 0.25mm ID x1 EM df, composed of 100\% dimethyl polysiloxane), operating in an electron impact mode at70eV; helium $(99.999 \%)$ was used as a carrier gas at a constant flow of $1.51 \mathrm{ml} /$ minutes.

\section{CONDITION}

Injection volume- $1 \mu \mathrm{L}$ through autosampler split ratio- $10: 1$; injection temperature $2400^{\circ} \mathrm{C}$; ion source temperature $2000^{\circ} \mathrm{C}$; Oven temperature was programmed from $700^{\circ} \mathrm{C}$ (isothermal for 2 minutes), with an increase of $100^{\circ} \mathrm{C} /$ minutes to $3000^{\circ} \mathrm{C} /$ minutes, ending with a 9 minutes isothermal at $3000^{\circ} \mathrm{C}$. Mass spectra were taken at $70 \mathrm{eV}$; with a scan range of $40-1000 \mathrm{~m} / \mathrm{z}$. Solvent cut time was 5 minutes; MS start time being 5 minutes; MS end time being 35 minutes; lon source temperature was set to $2000^{\circ} \mathrm{C}$ and interface temperature being $2400^{\circ} \mathrm{C}[18]$.

\section{Identification of bioactive compounds}

Bioactive compounds from the plant extract were identified based on retention time. Interpretation of mass spectrum of GC-MS was done using the database of National Institute Standard and Technology (NIST). The compound name, molecular weight, molecular formula, and structure were ascertained. The peak in GCMS of ethanol extract of leaf of Hellenia speciosa represents the presence of the secondary phytochemical compounds like lipid, steroid, alkaloid, and fatty acids and its esters.

\section{Results}

GC-MS is the best technique to identify the bioactive constituents of long-chain hydrocarbons, alcohols, acids, esters, alkaloids, steroids, amino and nitro compounds, etc. Hence, Gas chromatography (GC) and Mass spectroscopy (MS) associated with particular detection techniques have become sophisticated means for analysis of various compounds [19]. The GC-MS chromatogram of the ethanolic extract of Hellenia speciosa showed the peaks indicating the presence of 17 bioactive compounds in Fig. 4. The compounds with their Retention time (RT), Molecular formula, Molecular weight, and Area percentage were presented in Table 1. 
Table 1

Compounds identified in the leaf extract of Hellenia speciosa

\begin{tabular}{|c|c|c|c|c|}
\hline S.No & Name of the compound & RT & Area \% & Molecular Formula \\
\hline 1 & Thymol & 10.019 & 3.59 & $\mathrm{C}_{10} \mathrm{H}_{14} \mathrm{O}$ \\
\hline 2 & Caryophyllene & 11.854 & 0.62 & $\mathrm{C}_{15} \mathrm{H}_{24}$ \\
\hline 3 & Caryophyllene oxide & 13.919 & 1.34 & $\mathrm{C}_{15} \mathrm{H}_{24}$ \\
\hline 4 & Beta Asarone & 14.142 & 9.38 & $\mathrm{C}_{12} \mathrm{H}_{16} \mathrm{O}_{3}$ \\
\hline 5 & Artumerone & 14.795 & 1.35 & $\mathrm{C}_{15} \mathrm{H}_{20} \mathrm{O}$ \\
\hline 6 & Bicyclo[3.1.1]heptane,2,6,6, trimethyl & 14.795 & 1.35 & $\mathrm{C}_{10} \mathrm{H}_{18}$ \\
\hline 7 & Hexadecanoicacid,methyl ester & 17.536 & 2.77 & $\mathrm{C}_{17} \mathrm{H}_{34} \mathrm{O}_{2}$ \\
\hline 8 & Dibutylpthalate & 17.848 & 1.98 & $\mathrm{C}_{16} \mathrm{H}_{22} \mathrm{O}_{4}$ \\
\hline 9 & 9,12-Octadecanoic acid methyl ester & 19.163 & 1.81 & $\mathrm{C}_{19} \mathrm{H}_{34} \mathrm{O}_{2}$ \\
\hline 10 & Squalene & 24.980 & 1.19 & $\mathrm{C}_{30} \mathrm{H}_{50}$ \\
\hline 11 & Piperine & 25.745 & 3.11 & $\mathrm{C}_{17} \mathrm{H}_{19} \mathrm{NO}_{3}$ \\
\hline 12 & Beta Tocopherol & 26.681 & 2.88 & $\mathrm{C}_{28} \mathrm{H}_{48} \mathrm{O}_{2}$ \\
\hline 13 & Vitamin $\mathrm{E}$ & 27.290 & 2.64 & $\mathrm{C}_{29} \mathrm{H}_{50} \mathrm{O}_{2}$ \\
\hline 14 & Progesterone & 29.608 & 3.18 & $\mathrm{C}_{21} \mathrm{H}_{30} \mathrm{O}_{2}$ \\
\hline 15 & Caparratriene & 29.861 & 9.72 & $\mathrm{C}_{15} \mathrm{H}_{26}$ \\
\hline 16 & Testosterone & 30.730 & 5.81 & $\mathrm{C}_{19} \mathrm{H}_{28} \mathrm{O}_{2}$ \\
\hline 17 & 2-Bromo 4,5- dimethoxycinnamic acid & 33.181 & 9.44 & $\mathrm{C}_{11} \mathrm{H}_{11} \mathrm{BrO}_{4}$ \\
\hline
\end{tabular}

The major bioactive compounds identified were Thymol (RT-10.019;3.59\%), Caryophyllene oxide (RT13.919;1.34\%), Caryophyllene (RT-11.854:0.62\%), Artumerone (RT-14.795;1.35\%), Hexadecanoic acid methyl ester (RT-17.536;2.77\%), 9,12-Octadecanoic acid methyl ester (RT-19.163;1.35\%), Squalene (RT24.980;1.19\%), Piperine (RT-25.745;3.11\%), Beta Tocopherol (RT-26.681;2.88\%), Vitamin E (RT27.290;2.64\%), Caparratriene (RT-29.861;9.72\%), Progesterone (RT-29.608;3.18\%) and Testosterone (RT$30.73 ; 5.81 \%)$. The name of the major compounds and their bioactivity were highlighted in Table 2. 
Table 2

Bioactivity of compounds identified in Hellenia speciosa leaf extract

\begin{tabular}{|c|c|c|c|}
\hline $\begin{array}{l}\text { Name of the } \\
\text { compound }\end{array}$ & $\begin{array}{l}\text { Molecular } \\
\text { weight }\end{array}$ & $\begin{array}{l}\text { Nature of } \\
\text { compound }\end{array}$ & Activity \\
\hline Thymol & 150 & Monoterpene & Antifungal, antiseptic, antibacterial \\
\hline Caryophyllene & 204 & $\begin{array}{l}\text { Bicyclic } \\
\text { sequiterpene }\end{array}$ & $\begin{array}{l}\text { Anti-inflammatory, anticancer, Antioxidant, } \\
\text { antimicrobial, analgesic }\end{array}$ \\
\hline $\begin{array}{l}\text { Caryophyllene } \\
\text { oxide }\end{array}$ & 220 & $\begin{array}{l}\text { Bicyclic } \\
\text { sesquiterpenes }\end{array}$ & Anti-inflammatory, anticancer, antifungal, analgesic \\
\hline Artumerone & 216 & Aromatic & $\begin{array}{l}\text { Anticancer, Antivenom. Antidepresseur, Anti- } \\
\text { inflammatory, Neuroprotection activities }\end{array}$ \\
\hline $\begin{array}{l}\text { Hexadecanoic } \\
\text { acid methyl } \\
\text { ester }\end{array}$ & 270 & $\begin{array}{l}\text { Methyl } \\
\text { Palmitate }\end{array}$ & Antifungal, antibacterial \\
\hline $\begin{array}{l}9,12- \\
\text { Octadecanoic } \\
\text { acid methyl } \\
\text { ester }\end{array}$ & 294 & $\begin{array}{l}\text { Linoleic acid } \\
\text { methyl ester }\end{array}$ & Anticancer \\
\hline Squalene & 410 & Lipid & Antioxidant, Antitumor \\
\hline Piperine & 285 & Alkaloid & $\begin{array}{l}\text { Antihypertensive, antioxidant, antitumor, } \\
\text { anticonvulsant, anti-inflammatory, antibacterial, } \\
\text { antifungal, anti-thyroid, hepato-protective, } \\
\text { insecticidal, larvicidal activities }\end{array}$ \\
\hline Vitamin E & 430 & $\begin{array}{l}\text { Fat soluble } \\
\text { vitamin }\end{array}$ & $\begin{array}{l}\text { Anti-oxidant, anti -inflammatory, inhibition of } \\
\text { platelet aggregation, immune enhancing activity }\end{array}$ \\
\hline Progesterone & 314 & Steroid & Regulate blood pressure, reproduction \\
\hline Caparratriene & 206 & Sesquiterpene & Cytotoxicity (CEM leukemic cell $-\mathrm{IC}_{50} 3.0 \times 10^{-6} \mathrm{M}$ ) \\
\hline Testosterone & 288 & Steroid & Reproduction \\
\hline
\end{tabular}

\section{Discussion}

GC-MS analysis of phytoconstituents in the ethanolic leaf extracts of Hellenia speciosa highlights the pharmaceutical importance of the plant. The identified bioactive compounds occupy many biological properties. The presence of fatty acid esters such as hexadecanoic acid methyl ester and 9,12octadecenoic acid methyl ester have various bioactivities including antifungal, antioxidant, hypocholesterolemic, nematicide, pesticide, antiandrogenic, hemolytic, 5-alpha reductase inhibitor, and antimicrobial activity [20]. The results are by previous studies carried out by Sudha in aerial parts of Fluggea lucopyrus in 2013 [21]. The 9, 12 octadecadienoic acid methyl ester was also found to have potential cancer-preventive, anti-inflammatory, and antiarthritic activities [22]. A similar result was 
observed in the study carried out in Croton tiglium seed by Mangunwidjaja et al., in 2006 [23]. Squalene is a triterpene with anticancer, antioxidant, chemopreventive, gastroprotective, hepatoprotective effects, antitumor, and sunscreen properties [1]. Alkaloids provide the underlying structure for the development of several antibiotics with a diverse range of action [24]. Piperine is an alkaloid used in the field of traditional medicine to treat various illnesses. Piperine may help reduce inflammation, the reduction of pain [25], improving digestion, and relief of Asthma. It has also been extensively used as an antidepressant [26], antioxidant [27],[28]. Ar-tumerone is one of the major bioactive compounds present in the plant extract. It inhibits microglia activation a property that may be useful in treating neurodegenerative disease [29]. Ar-turmerone also possesses anti-inflammatory properties as reported by [30].

Caryophyllene and caryophyllene oxide were also identified as major compounds in leaf extract and found to possess anticancer and analgesic properties [31]. Caryophyllene oxide shows potent antimicrobial against various pathogens causing damage to the cell membrane [32],[33],[34]. In addition to this, the antifungal property has also been reported by Sagbo and Mbeng in 2019 [35]. Several biological activities were attributed to caryophyllene, such as anti-inflammatory, antibiotic, antioxidant, anticarcinogenic, and local anaesthetic. Similar studies have been reported by different researchers in different plant extracts [25],[31]. Caryophyllene, Caryophyllene oxide, and Squalene can induce apoptosis and cell cycle arrest in the G1 phase of the cells [36]. Progesterone and testosterone are the major steroid hormones that play an important role in reproduction. In the present study presence of these compounds have been reported. Vitamin $\mathrm{E}$ is one of the major compounds detected in the ethanol extract has been found to exhibit antioxidant, anti-inflammatory, antimicrobial [36]. Vitamin E prevents lipid peroxidation and function as an antioxidant, its role in anti-inflammatory processes, its inhibition of platelet aggregation, and its immune-enhancing activity [37]. An article by Radhakrishnan et al. proved that daily supplementation of Vitamin E can enhance the immune response to a specific antigen [38].

\section{Conclusion}

GC-MS analysis of ethanolic leaf extract of Hellenia speciosa revealed the presence of bioactive compounds like fatty acid, heterocyclic compounds, steroids, alkaloids, terpenoids, and vitamins. Among the identified compounds, Octadecanoic acid, n-Hexadecanoic acid, Caryophyllene, Ar-tumerone. Piperine and Squalene are the major compounds that might contribute to biological activities such as antioxidant, antimicrobial, anticancer, antidiabetic, and anti-inflammatory properties. Therefore, the present study results conclude that Hellenia speciosa may serve as a potent source of medicinal activity due to the presence of bioactive compounds. However further studies are essential to isolate, characterize and purify the active components responsible for therapeutic activity.

\section{Declarations}

\section{Acknowledgement}


I would like to thank Dr. Kumar, Sathyabama Institute of Science and Technology, Chennai. for providing all the facilities and support to carry out the work.

Funding Not applicable

\section{Conflict of Interest}

The author declared that there is no conflict of interest.

Availability of data and material Not applicable

Code Availability Not applicable

\section{References}

1. Gomathi, D., Kalaiselvi, M., Ravikumar, G., Devaki, K., \& Uma, C. (2015). GC-MS analysis of bioactive compounds from the whole plant ethanolic extract of Evolvulus alsinoides (L.) L. J Food Sci Technol, 52(2), 1212-1217

2. WHO \& IUCN, W. W. F. (1993). Guidelines on the conservation of medicinal plants. Somerset, UK: Castle Cary Press

3. Gordon, M. C., \& David, J. N. (2001). Natural product drug discovery in the next millennium. J. Pharm Biol, 20, 201-202

4. Juszczak, A. M., Zovko-Končić, M., \& Tomczyk, M. (2019). Recent trends in the application of chromatographic techniques in the analysis of Luteolin and its derivatives. Biomolecules, 9(11), 731

5. Satapute, P., Murali, K. P., Kurjogi, M., \& Jogaiah, S. (2019). Physiological adaptation and spectral annotation of Arsenic and Cadmium heavy metal-resistant and susceptible strain Pseudomonas taiwanensis. Environ. Pollut, 251, 555-563

6. Fan, S., Chang, J., Zong, Y., Hu, G., \& Jia, J. (2018). GC-MS analysis of the composition of the essential oil from Dendranthema indicum Var. Aromaticum using three extraction methods and two columns. Molecules, 23(3), 576

7. Muniyandi, S. K., Nandanan, A. T., Veeti, S. C., Narayanan, A., \& Ganesan, B. (2013). Studies on Costus speciosus Koen Alcoholic Extract for Larvicidal Activity. International Journal of Pharmacognosy and Phytochemical Research, 5(4), 328-329

8. Pawar, V. A., \& Pawar, P. R. (2014). Costus speciosus: An important medicinal plant. International Journal of Science and Research, 3(7), 28-33

9. Ariharan, V. N., Meena, Devi, V. N., Rajakokhila, M., \& Prasad, P. N. (2012). Antibacterial activity of Costus speciosus rhizome extract on some pathogenic bacteria. International Journal of Advanced Life Sciences, 4, 24-27

10. Srivastava, S., Singh, P., Mishra, G., Jha, K. K., \& Khosa, R. L. (2011). Costus speciosus (Keukand): A review. Der Pharmacia Sinica, 2 (1),118-128. 
11. Rani, A. S., Sulakshana, G., \& Patnaik, S. (2012). Costus speciosus, an antidiabetic plant-review. FS J Pharma Res, 1(3), 52-53

12. Saraf, A. (2010). Phytochemical and antimicrobial studies of medicinal plant Costus speciosus (Koen.). Chem, 7, S40513.

13. ElFar, A. H., Hazem, Shaheen, H. M., Alsenosy, A. W., ElSayed, Y. S., Jaouni, A., \& Mousa, S. K., SA. (2018). Costus speciosus: Traditional Uses, Phytochemistry, and Therapeutic Potentials. Pharmacognosy Reviews, 12(23), 120-127

14. Pizzale, L., Bortolomeazzi, R., Vichi, S., \& Conte, L. S. (2002). Antioxidant activity of Sage and Oreganao extracts related to their phenolic compound content. Journal of the science of food and agriculture, $82,1645-1651$

15. Lee, Y., \& Foo, Y. (2001). Antioxidant activities of polyphenols from Salvia officinatis. Food chem, 75, 197-202

16. David, O., Zelda, S., \& Fulton, P., GK. (2011). Gas chromatography and Mass spectrometry. A Practical Guide (2nd ed.). Academic Press

17. Rukshana, M. S., Doss, A., \& Kumari Pushpa Rani, T. P. (2017). Phytochemical Screening and GC-MS Analysis of leaf Extract of Pergularia daemia (Forssk) Chiov. Asian Journal of Plant Science and Research, 7(1), 9-15

18. Bagavathi, P. E., \& Ramasamy, N. (2012). GC-MS Analysis of Phytocompounds in the Ethanol extracts of Polygonum chinense L. Pharmacognosy Research, 14, 11-14)

19. Velmurugan, G., \& Anand, S. P. (2017). GC-MS Analysis of Bioactive Compounds on Ethanolic Leaf Extract of Phyllodium pulchellum L. Desv. International Journal of Pharmacognosy and Phytochemical Research, 9(1), 114-118

20. Parimalakrishnan, S., Akalanka, D., Rajeswari, J., \& Ravikumar, K. (2015). Extraction and Characterization of Phytoconstituents Cleome chelidonii by GCMS. International Journal of Chemical and Pharmaceutical Sciences, 6(1), 63-69

21. Sudha, T., Chidambarampillai, S., \& Mohan, V. R. (2013). GC-MS Analysis of Bioactive Components of Aerial parts of Fluggea leucopyrus Wild. (Euphorbiaceae). Journal of Applied Pharmaceutical Science, 3(05), 126-130

22. Parthipan, B., Suky, M. G. T., \& Mohan, V. R. (2015). GC-MS Analysis of Phytocomponents in Pleiospermium alatum (Wall. ex Wight \& Arn.) Swingle, (Rutaceae). Journal of Pharmacognosy and Phytochemistry, 4(1), 216-222

23. Mangunwidjaja, D. S., Kardono, S. R., \& Iswantini, L. B. (2006). Gas chromatography and Gas Chromatography-Mass Spectrometry analysis of Indonesian Croton tiglium seeds. J.Applied Sci, 6, $1576-1580$

24. Othman, L., Sleiman, A., \& Abdel-Massih, R. M. (2019). Antimicrobial Activity of Polyphenols and Alkaloids in Middle Eastern Plants. Front. Microbiol, 10, 911

25. Ghaidaa, J. M., Omran, A. M., \& Hussein, H. M. (2016). Antibacterial and Phytochemical Analysis of Piper nigrum using Gas Chromatography - Mass Spectrum and Fourier-Transform Infrared 
Spectroscopy. International Journal of Pharmacognosy and Phytochemical Research, 8(6), 977-996

26. Li, S., Wang, C., Wang, M., Li, W., Matsumoto, K., \& Tang, Y. (2007). Antidepressant like effects of Piperine in chronic mild stress treated mice and its possible mechanisms. Life Sci, 80(15), 13731381

27. Rauscher, F. M., Sanders, R. A., \& Watkins, J. B. (2000). Effects of piperine on antioxidant pathways in tissues from normal and streptozotocin induced diabetic rats. J Biochem Mol Toxicol, 14, 329-334

28. Prakash, U. N., \& Srinivasan, K. (2010). Gastrointestinal protective effect of dietary spices during ethanol-induced oxidant stress in experimental rats. Appl Physiol Nutr Metab, 35(2), 134-141

29. Hucklenbroich, J., Klein, R., \& Neumaier, B. (2014). Aromatic-turmerone induces neural stem cell proliferation in vitro and in vivo. Stem Cell Research Therapy, 5, 100

30. Park, S. Y., Kim, Y. H., Kim, Y., \& Lee, S. J. (2012). Aromatic-turmerone's anti-inflammatory effects in microglial cells are mediated by protein kinase A and heme oxygenase-1 signaling. Neurochem Int, 61, 767-777

31. Fidyt, K., Fiedorowicz, A., Strzadala, L., \& Szumny, A. (2016). Beta-caryophyllene and betacaryophyllene oxide-natural compounds of anticancer and analgesic properties. Cancer Med, 5 , 3007-3017

32. Kamazeri1, T. S., Samah, O. A. 1, Taher, M., \& Susanti1, D. (2012). Qaralleh H. Antimicrobial activity and essential oils of Curcuma aeruginosa, Curcuma mangga, and Zingiber cassumunar from Malaysia.Asian Pacific Journal of Tropical Medicin,202-209.

33. Koheil, M., Khalek, S. A., El-Hefnawy, H., El-Deen, A. S., \& Haleem, M. A. (2012). Composition and Antimicrobial Activity of the Essential Oil of Pelargonium zonale L. from Egypt. J. Biol. Act. Prod. Nat, $2,178-185$

34. Neeranjna, M., \& Kumar, D. N. J(2019). Comparative phytochemical screening of Curcuma angustifolia, Curcuma decipiens and Curcuma longa by using GC-MS. Journal of Pharmacognosy and Phytochemistry, 8(2), 1227-1234.

35. Sagbo, I. J., \& Mbeng, W. O. (2019). Chemical Constituents, Anti-Oxidative, Cytotoxic and Genotoxic Effects of Miscathus Capensis Roots Extract. Asian Journal of Pharmaceutical and Clinical Research, 2019,12, 227-232

36. Nguyen, N. H., Nguyen, T. T., Ma, P. C., Hoai Ta, Q. H., Duong, T. H., \& Vo, V. G. (1996). Potential Antimicrobial and Anticancer Activities of an Ethanol Extract from Bouea macrophylla. Molecules, 25,1996

37. Saliha, R., Syed, T., Raza, Faizal, A., Absar, A., Shania, A., \& Mahdi, F. (2014). The Role of Vitamin E in Human Health and some Diseases. Sultan Qaboos University medical journal, 14(2), 157-165

38. Radhakrishnan, A. K., Lee, A. L., Wong, P. K., Kaur, J., Aung, J., \& Nesaretnam, K. (2014). Comparable effects on immune modulation following daily supplementation with tocotrienol-rich fraction (TRF) or alpha-tocopherol in normal human volunteers. British Journal of Nutrition, 101(6), 810-815

\section{Figures}




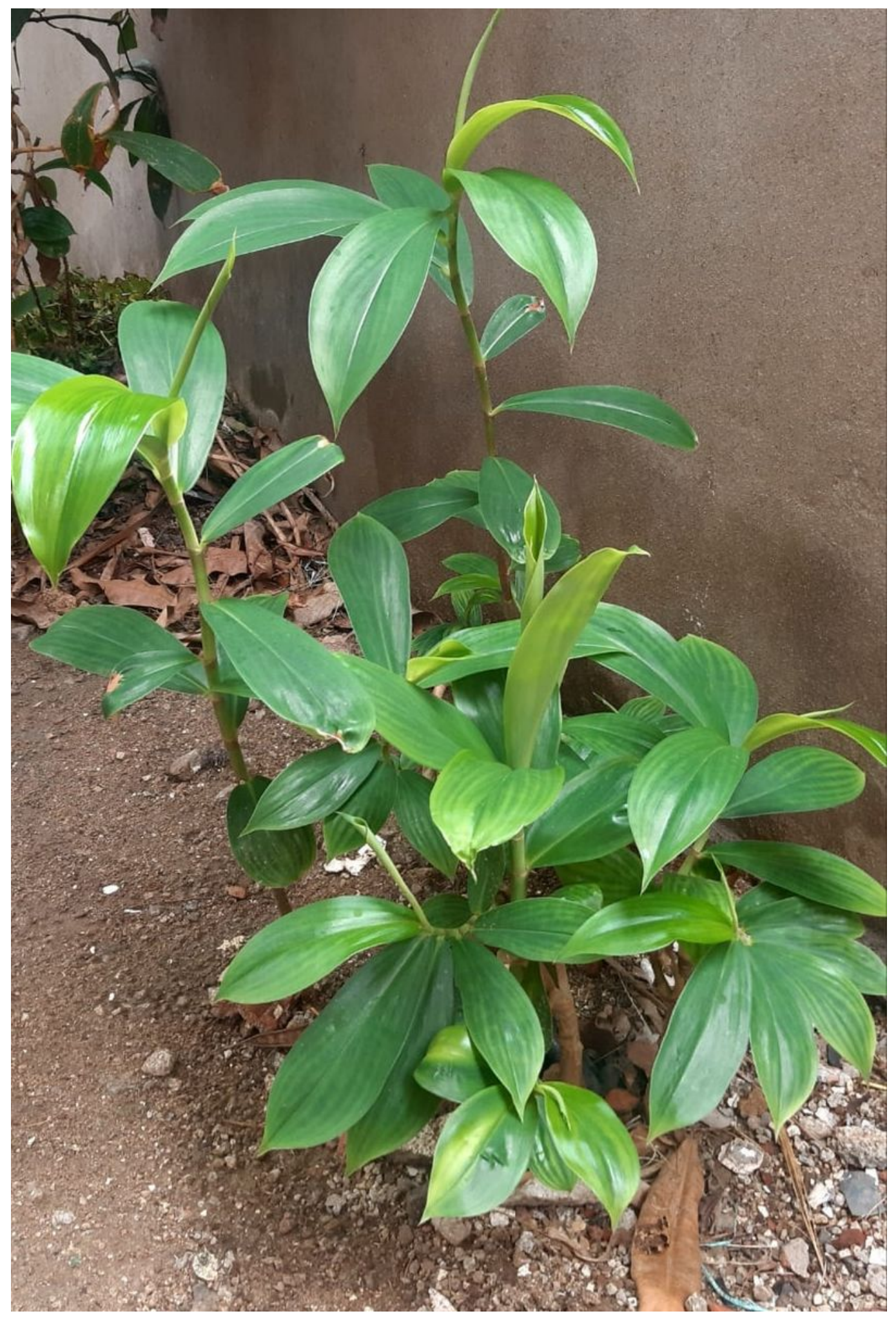

Figure 1

Hellenia speciosa 


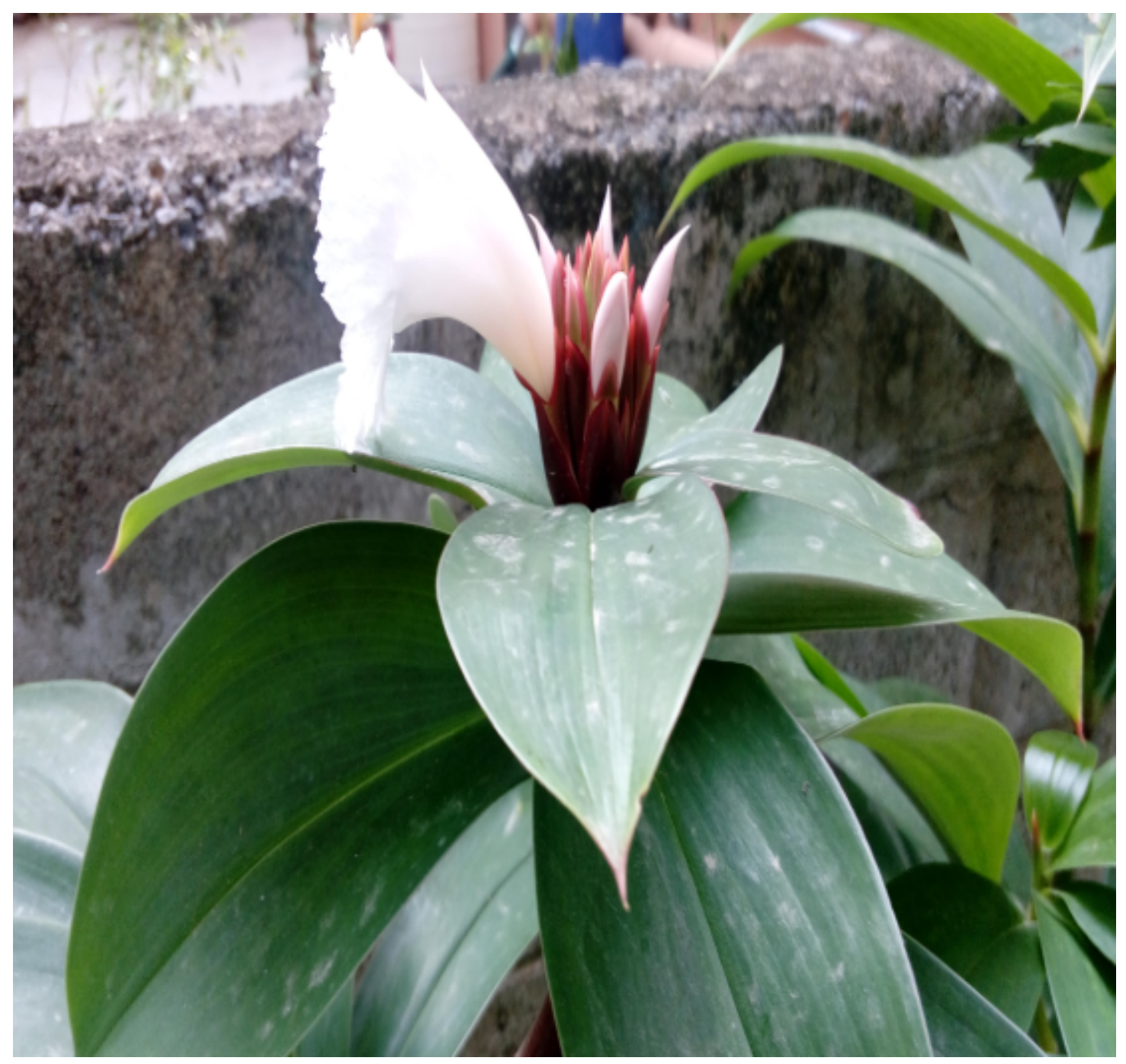

Figure 2

Flower of Hellenia speciosa

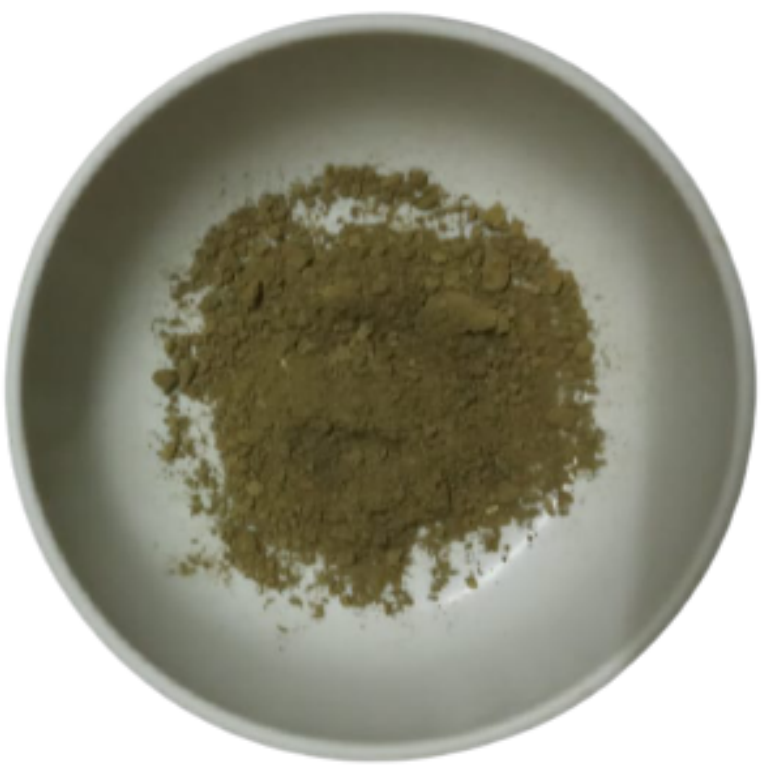


Figure 3

Dry powder of Hellenia speciosa

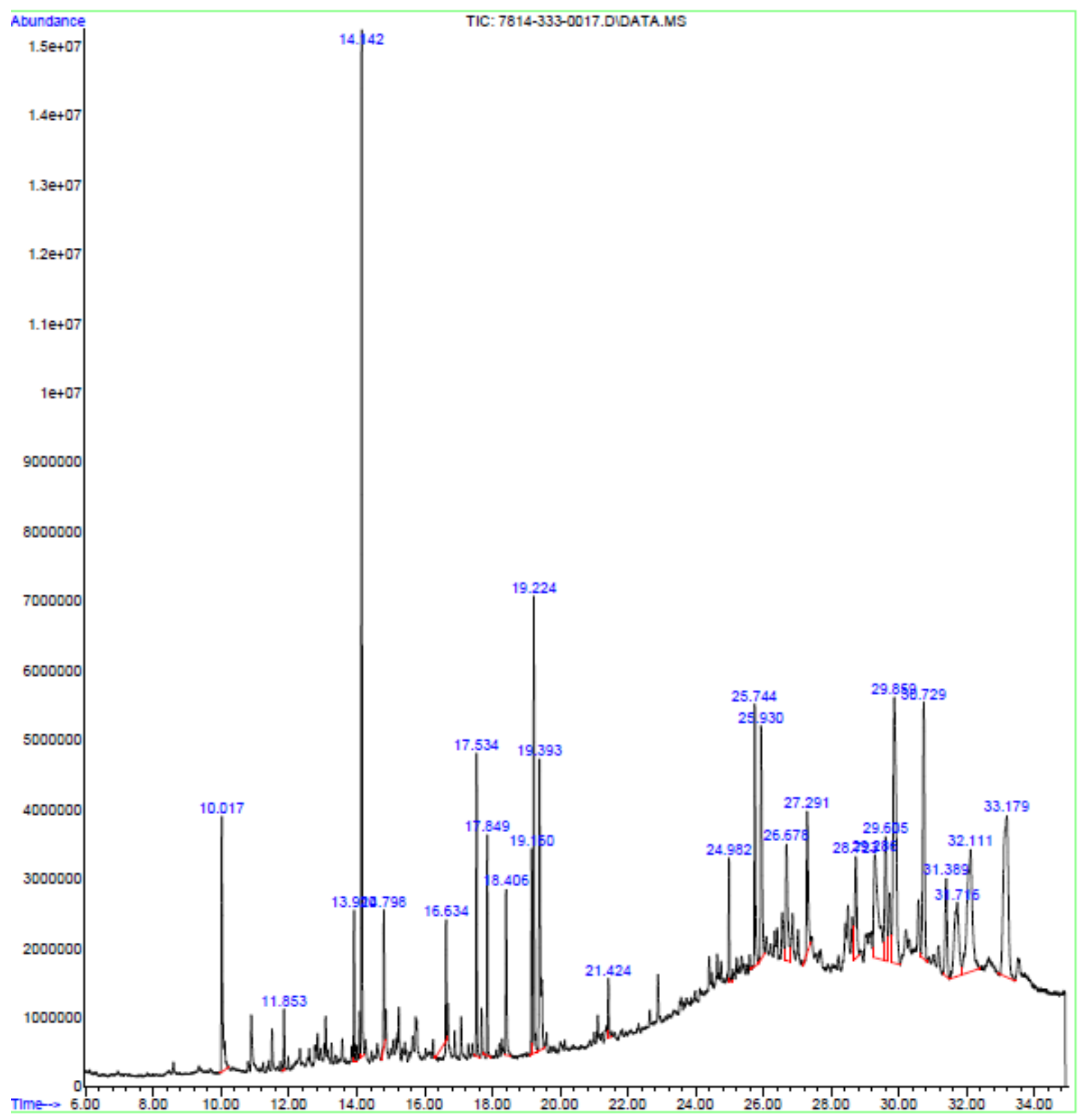

Figure 4

GC-MS Chromatogram of Ethanolic extract of Hellenia speciosa 